\title{
Demographics factors and awareness on Shariah-based Private Retirement Scheme among higher learning institution students in Malaysia
}

\section{Solehah Yahaya *, Haslindar Ibrahim * (D), Abdul Hadi Zulkafli * (D), Mohd Shahril Ahmad Razimi ** (D)}

* Universiti Sains Malaysia,

11800 USM Penang, Malaysia

** Universiti Utara Malaysia,

06010 UUM Sintok, Kedah Darul Aman, Malaysia

Head of Department (Islamic Business)

\section{open (e)access ce dol}

Article history:

Received: September 25, 2017

1st Revision: October 1, 2017

Accepted: October 25, 2017

\section{JEL classification:}

J26

$\mathrm{J} 32$

$\mathrm{Z} 1$

Z12

DOI:

10.14254/jems.2017.2-2.9

\begin{abstract}
This study is conducted to identify the demographic factors that influencing the awareness of Shariah-based Private Retirement Scheme (PRS) among undergraduate and postgraduate business students in higher learning institution in Malaysia. The purpose of this study is to identify the significant differences between determinant factors namely gender, age, religion, student's level of education and background of education on the awareness of Shariahbased PRS. A total number 380 respondents among public university students are selected as respondents of a survey which are randomly distributed. The data is analysed using T-test and One-way ANOVA. The finding shows that demographic factors consist of gender, age, religion, education level, and background of study are significantly different towards awareness of Shariah-based PRS. This study will create more awareness not only for fresh graduates but also employees to start having a retirement plan if they do not have any yet.
\end{abstract}

Keywords: awareness, Shariah-based PRS, retirement planning.

\section{Introduction}

Retirement planning is one of the financial planning processes for an individual or a family. In order to sustain comfortably if one were to retire, it is important to create sources of income for retiree. The view that Muslims have and understand is that Allah is the owner of every wealth in this world while human being serves as a Caliph in managing His world. Hence, it is important for

Corresponding author: Abdul Hadi Zulkafli

E-mail: hadi_zml@usm.my

This open access article is distributed under a Creative Commons Attribution (CC-BY) 4.0 license. 
His creatures especially human to cleverly manage His wealth as the concept of financial planning is based on Islamic concept. He mentioned this in the His holy book, the Quran:

[Yusuf] said, "You will plant for seven years consecutively; and what you harvest leave in its spikes, except a little from which you will eat.

(Al-Quran, 12: 47)

Based on the above verse, Islam has taught every Muslims to have a good planning in ensuring the achievement of their goal or target. This is also applicable to financial planning as it is crucial for people to do to ensure that their goal of life is achieved. Moreover, a hadith which was narrated by Al Hakim, as Prophet (pbuh) said that; "Take benefit of five things before the five things, that is your youth before your old age, your health before your sickness, your wealth before your poverty, your free time before you are preoccupied, and your life before your death" (Narrated by $\mathrm{Al}$ Hakim, Kitab al-Mustadrak, 4, 341).

From the above hadith, it strongly reminds Muslims to have prevention plans which must be in good manner. The plan serves as assurance that human need to focus on planning for the future in order to guarantee a better life. For example in the retirement plan we have to ensure that our financial planning is paralleled with what is needed in the future, especially on the retirees' daily expenses. As Islam teaches us from the above hadith that we have to plan for the better from young for the betterment for our old age. We also need to allocate some savings for the difficult times.

Apart from Islamic philosophy in having good plan for future time, it is identified that it is hard to create awareness about retirement planning among youth mostly college students. They do not care enough about their retirement planning. According to James, Hadley, and Maniam (2002) they claim that most college students fail to understand the importance of having retirement planning because they do not care about it. They found out from their study that students' main concern is to find a job and start their new career once they are graduated. Hence, they could not grasp the idea of having a plan for their retirement planning when they just only begun.

Furthermore, not many researchers studied the awareness among youths in financial products study. Harisson, Waite and White (2006) in their findings claim that not many researches have studied the awareness of youths in financial products or services probably due to infrequent timing of purchases and the complexity in streamlining products offered by financial institutions.

In that respect, the present study is set to investigate the effect of demographic factors namely gender, age, religion, education level, and background of study which focuses on having Shariah-based PRS. Based on the above identified issues this study is highly significant to be carried out.

\section{Literature review}

Shariah-based PRS is based on the Wakalah principle. Wakalah principle is a fee based contract. PRS providers act as agent that manage members' fund. They are responsible in managing PRS members' fund to invest into Shariah compliance stocks as listed by Security Commission (SC). It has three core funds that are similar with the conventional PRS. These three core funds are Growth funds, Moderate funds, and Conservative funds. Every funds are different according to the asset allocation for the investment purpose. Shariah-based PRS members are allowed to invest under default option funds that is based on the member's age, or based on the member's risk appetite. These three core funds under the Shariah-based PRS are discussed below.

First is growth fund that offered for members with a moderate to high risk appetite. This type of funds is more flexible. $30 \%$ to $70 \%$ of the fund's net asset value (NAV) will be invested into Shariah compliance equities, sukuk, and Islamic money market instruments. This fund is also approved to be invested outside Malaysia to give more investment opportunities and increasing the returns from investment. But, it is subject to $30 \%$ of the funds NAV and limited to Asia Pacific region. This type of funds is eligible for those who are in age between 20 to 40 years old under default option.

Second is moderate fund that is suitable for those who have a moderate risk appetite, or based on the default option. Default option is for those in age range between 40 to 50 years old. The asset allocation for this fund is based on the minimum of $40 \%$ and maximum $60 \%$ of the funds' NAV that will be invested in Shariah compliance equities and equity related securities. The balance portion of funds will be invested in sukuk, Islamic money market instruments and Islamic deposit with financial institution. This fund can also be invested outside Malaysia for better return, but only in Asia Pacific region.

Third is conservative fund which is for those who have a low risk appetite and seek regular distribution of units from their contributions, for default option is for the members 50 years and 
above. Ir distributes a minimum of $80 \%$ of the fund's NAV in Malaysian sukuk and Islamic money market instruments of which a minimum $20 \%$ of the fund's NAV will be invested in Islamic money market instruments. A maximum of $20 \%$ are allowed to be invested in Malaysian Shariahcompliance stock market and the permission of the investment is only in Malaysian stock market.

A study from Amin (2007) on Borneo Islamic automobile financing found that bank customers are homogenous in term of awareness and usage of the Islamic financing. It is supported by the significant differences in the demographic factors like gender, race, education and income level. Additionally, researcher also highlighted from their research that the demographics factors are the best determinants in studying the individual preferences towards the Islamic finance transactions.

Consequently, Doarisamy, Shanmugam, and Raman (2011) conclude from their study that demographic factors are significant with customers' preferences on the Islamic finance's business and transactions. In addition demographic factors have a significant relation with the awareness on the Islamic banking transactions (Khattak \& Rehman, 2010). They point out that the awareness of Islamic banking products are different among the different range of age and also the academic qualification of the customers.

On the other hand, Haque, Osman, and Ismail (2009) argue with the above result of study. They claim that the demographic factors do not have a significant relationship with the preferences towards the Islamic banks" products and services as they found that $95 \%$ does not have significant relationship with the perception towards the Islamic banking products.

Gender has substantial relations towards the perception on the Islamic banking. According to Haque et al. (2009) they found that male and female have different perceptions on Islamic banking as they found that the significant value for gender is 0.014 . It indicates that male and female has different significant perception on Islamic banking.

In this manner, men are likely to have high financial knowledge compared to women. The study conducted by Chen and Volpe (2002) found that men have a better financial knowledge than women, as women respondent's score in answering questions correctly is only $51 \%$ compared to the men respondents, as they have managed to obtain $57 \%$ in the survey.

Nevertheless, according to Clark, d'Ambrosio, McDermed, and Sawant (2006), women are planning to retire earlier than men, and also have a low income goal. For this goal, women have an investment plan for the asset allocation and they are also willing to have a high contribution for their retirement plan since they are at younger age compared to men. But according to Tennyson and Nguyen (2001), they found that there is no significant relation between the genders towards the knowledge of the personal financing.

Age is considered as influencing the perception towards Islamic banking product and services. According to Haque et al. (2009) they found that age does have a large relation towards the perception on the Islamic bank with the significant value of 0.067 . It is also supported by Khattak and Rehman (2010) in which they conclude from their study that age has a significant relationship on the awareness of the Islamic banking products. From their study, they also found that most of the Islamic bank customers are between 21 to 40 years old. Khan, Hassan, and Shahid (2008) found that most of the customers in the Islamic bank in Bangladesh are among the young individuals between 25 to 35 years old.

At the same time, a study by Amin (2007) argues that the age has a significant relation towards the awareness on the Islamic financial products. From his point of view, there is no significant between the ages with the awareness towards the Islamic banking product with significant value is 1.861 . From that it clearly proven that age was insignificant towards awareness on Islamic banking product and services.

As the result obtained by Loo (2010) he observed that the religion is the main determinant for the Muslim respondents in choosing the Islamic banking services that is rank about $85 \%$. It is followed by the products and services, reliability, and others factors respectively.

On the other hand some studies regarding religion are does not important factor for determining Islamic bank customers to choose Islamic finance products. As the study done by Abdullah and Dasuki (2006) they suggest that Islamic banks should promote their banking products well instead of depending on the religion as the main factor for the customer to choose an Islamic banking product. They found that the most important factors are skill, kindliness and the quality of services.

It is also supported by Yusof (1999) by saying that profit is the one motivation for consumers in adopting the Islamic banking business and transaction. The result shows that $85 \%$ of nonMuslims respondents agree that the profit distribution is the reason that motivates them in adopting the Islamic bank business, whereas for Muslim respondents it is about $15 \%$.

From previous study it was found that even though a student has a good education background, but they still lack of financial knowledge. According to Chen and Volpe (1998) they 
found that most of the students have lack of financial knowledge in which may lead them to make wrong decision for their financial choice. One of the factors that influences this is even though they possess good level of education in college, they may be lack of financial knowledge due to the lack of personal financial education in the courses offered by the college.

Moreover, Tennyson and Nguyen (2001) support that students who are strictly mandated to study the financial knowledge have a high financial knowledge compared to those who are not obligated to learn about it. In addition, Khattak and Rehman (2010) found that academic qualification also influenced the financial decision knowledge. They also noticed that the academic qualification has an important relation with Islamic banking services like the banking charge.

Although this may be true but, Haque et al. (2009) discovered an opposite result from their study about the level of education towards the perception on the Islamic bank. They found that the level of education does not influence the perception towards the Islamic bank services among the students. It is proven with the significant value from their test in which it is only 0.613 . So they conclude from their study that the level of education does not have a big different towards the perceptions towards the Islamic banking services.

For the courses or background of study between colleges students it was determined that student who study a business courses are more knowledgeable about financial knowledge compared to non-business students. According to Chen and Volpe (1998), students who undertake the business courses are more knowledgeable in financial knowledge compared to the nonbusiness students. From their survey, $60.72 \%$ business students answered correctly compared to the non-business students, which only $49.94 \%$ managed to give the correct answers.

However according to Dale and Bevill (2007), they found an opposite result. They found that the major courses that students study in college do not give them any knowledge on credit card especially the interest charge. They found that $86 \%$ of all respondents did not know about the interest rate charge for their credit card. To summarize, even students who study in business background do not realise certain agreement and requirements when dealing with the banking facilities.

\section{Methodology}

Students from public university students have participated in this study. They are from three level of education background that is degree, master, and Phd level of study. Students from business related programmes on one of public university in Malaysia are chosen as a population for this study. 500 set of questionnaires was distributed and only 370 respondents respond to this survey. Before the actual survey, the questionnaires were pre-tested on 30 prospective students. Then the data was testing for normality and reliability test.

Independent variables of the present study are demographic factors that are gender, age, religion, student's level of education and background of study. Dependent variable of this study is awareness. For this awareness variable seven questions about awareness toward Shariah-based PRS adapted from Amin (2007). Those seven questions were; (1) I'm generally aware of Islamic banking product and services, (2) I'm aware of the retirement scheme in Malaysia such as Government Pension Scheme (GPS), and Employment Provident Funds (EPF), (3) I'm aware of the Shariah-based Private Retirement Scheme (PRS) products offered in Malaysia, (4) I'm aware some of the providers that offered Shariah-based Private Retirement Scheme (PRS) such as AmFunds Management Berhad, CIMB Principle Asset Management Berhad and Public Mutual Berhad, (5) I'm personally aware the Shariah-based Private Retirement Scheme (PRS) that offered in Malaysia, (6) I'm aware that Shariah-based Private Retirement Scheme (PRS is free from prohibited elements like riba (interest), gharar (uncertainty) and maisir (gambling), (7) I'm aware of the Shariah-based Private Retirement Scheme (PRS). Each question was measured with five point's Likert scale ranging from strongly disagree (1-point) to strongly agree (5-point). The answer from seven questions was summed to create a scale of awareness towards Shariah-based Private Retirement Scheme (PRS) variables. Cronbach coefficient alpha was 0.750 . This figure is higher than 0.70 which is generally agreed upon lower limit for Cronbach's alpha value.

\section{Research findings}

\subsection{Demographic characteristics of the sample}

Descriptive statistics are presented in Table 1. A descriptive analysis on respondent demographic profile revealed that the numbers of male respondents are only 120 or $32.4 \%$ which is about only one third of the total respondents. On the other hand, female respondents are slightly 
higher than two thirds of the total respondents which are about 250 or $67.6 \%$. The total number of respondents for this study is 370 .

In addition there are three groups of respondent in terms of age. Based on Table 1, the age range of respondents are from below than 20 years old age groups, between 21 to 24 years old age groups and lastly the final group is 25 years old and above. Based on the Table 1 the respondents' age below than 20 years are 127 (34.3\%), followed by the age between 21 to 24 years which are about 149 (40.3\%) and finally 94 or $25.4 \%$ are from respondents of age 25 years and above.

Majority of the respondents for this study are Muslims with 276 (74.6\%) and followed by Buddhists (69 or 18.6\%). Christian respondents are only 15 or 4.1\%, and Hindus respondent is 10 $(2.7 \%)$ as shown in Table 1 . It is paralleled with the sample of the population that majority of students are Muslims.

Three groups with different level of education had been tested among respondents involving Undergraduate, Masters and Doctor of Philosophy (PhD) students. Based on Table 1, most of the respondents are represented by undergraduate students with a total of 255 respondents or $68.9 \%$ while 96 (25.9\%) are masters students. Respondents for PhD level students are only 19 (5.1\%).

Furthermore, since this study involves sampling among business students, most respondents are taking Islamic Business, Accounting, Business Management and Economic Finance and Banking course. Based on Table 1, majority of the students are from the Business Management study which are about 190 students (51.4\%). It is followed by the Economic, Finance and Banking course that is 92 students (24.9\%) respondents. Then for Accounting course which are about 48 students (13\%), and Islamic Business study course which are about 40 students (10.8\%) of respondents.

\begin{tabular}{lcc} 
Table 1: Descriptive statistic of variables & & \\
\hline Item & Frequency & Percentage (\%) \\
\hline Gender & 120 & 32.4 \\
Male & 250 & 67.6 \\
Female & $\mathbf{3 7 0}$ & $\mathbf{1 0 0}$ \\
Total & & \\
Age (years) & 127 & 34.3 \\
20 and below & 149 & 40.3 \\
21 to 24 & 94 & 25.4 \\
25 and above & $\mathbf{3 7 0}$ & $\mathbf{1 0 0}$ \\
Total & & \\
Religion & 276 & 74.6 \\
Muslims & 69 & 18.6 \\
Buddhists & 15 & 4.1 \\
Christians & 10 & 2.7 \\
Hindus & $\mathbf{3 7 0}$ & $\mathbf{1 0 0}$ \\
Total & & \\
Level of education & 255 & 68.9 \\
Degree & 96 & 25.9 \\
Masters & 19 & 5.1 \\
PhD & $\mathbf{3 7 0}$ & $\mathbf{1 0 0}$ \\
Total & & \\
Background of study & 40 & 10.8 \\
Islamic business & 48 & 13.0 \\
Accounting & 190 & 51.4 \\
Business Management & 92 & 24.9 \\
Economic finance and banking & $\mathbf{3 7 0}$ & $\mathbf{1 0 0}$ \\
Total & &
\end{tabular}

\subsection{Sample T-test analysis}

For this study researcher used Sample T-test to analyse the significant differences between male and female on awareness of Shariah-based PRS. The reason for conducting this test is to examine whether there is a significant difference between genders toward the awareness on the Shariah-based PRS.

The result between gender and awareness of Shariah-based PRS is presented in Table 2. It is found that the mean value for male (3.44) is higher than women (3.21). The t-test shows that it significant value is 0.001 that is less than 0.05 ( $\mathrm{p}$ value $<.05)$. Therefore, there is a significant difference between gender and the awareness of Shariah-based PRS. The results indicated that male respondents are more aware about Shariah-based PRS compared to female respondents. Thus 
result from this study is parallel with previous study. As according to Chen and Volpe (2002) they found that male has a better financial knowledge compared to female.

Table 2: The differences between gender and awareness of Shariah-based PRS

\begin{tabular}{lcccccc}
\multicolumn{1}{c}{ Gender } & N & Mean & $\begin{array}{c}\text { Standard } \\
\text { Deviation }\end{array}$ & T & Sig. \\
\hline $\begin{array}{l}\text { Awareness of } \\
\text { Shariah- } \\
\text { based PRS }\end{array}$ & Male & 110 & 3.44 & .647 & 3.3 & .001 \\
\hline
\end{tabular}

\subsection{One-way ANOVA analysis}

The result of the ANOVA involving age group analysis is presented in the Table 3 below. It is found that the significant level of the ANOVA test was 0.04 smaller than standard alpha .005. Based on ANOVA analysis students in age group 25 years and above has a high level of awareness if compared to others age group of respondents. Then, researcher performed further analysis using post hoc test of group differences. A close comparison of age group for the age below 20 years old and age between 21 to 24 years old $(p=0.623)$ as well as the age below 20 and age 25 years and above $(\mathrm{p}=0.047)$ are observed. It is showed that the student in age 25 years and above has a high level of awareness towards Shariah-based PRS if compared to other two age groups in this study. Results from this study are supported by Khattak and Rehman (2010). From their study they indicated that age has a significant relation towards awareness on Shariah-based product in banking institutions.

\begin{tabular}{|c|c|c|c|c|}
\hline Age group & Mean & Std. deviation & F value & Sig. \\
\hline Below 20 & 3.26 & .608 & 5.54 & $0.04^{*}$ \\
\hline 21 to 24 & 3.19 & .656 & & \\
\hline 25 and above & 3.46 & .543 & & \\
\hline
\end{tabular}

The result of the ANOVA analysis for religion is presented in the Table 4 below. Consistent with the earlier findings, it is also indicated that the significant level of the ANOVA test is 0.00 smaller than standard alpha .005. Thus we accept hypotheses that religion of the respondents is significant with the awareness of Shariah-based PRS and researcher concluded that at least two groups of religion are significantly different.

Further analysis using post hoc test of group differences is then conducted to identify the level of awareness among the respondents. A close comparison of religion is exhibited between Muslim and Buddhists ( $p=0.000)$, Muslim and Christians ( $p=0.246)$ also Muslim and Hindus $(p=1.000)$. It is concluded that Muslims and Hindus has a high level of awareness towards Shariahbased PRS compared to others religions. Thus this finding is parallel with Loo (2010) as they found that religion is the main determinant in choosing Islamic financing products among customers.

\begin{tabular}{lcccc}
\multicolumn{1}{c}{ Table 4: The difference between religion and awareness of Shariah-based PRS } & \\
\multicolumn{1}{c}{ Religion } & Mean & Std. deviation & F value & Sig. \\
\hline Muslims & 3.41 & .560 & & \\
Buddhists & 2.74 & .616 & 22.46 & .000 \\
Christians & 3.12 & .576 & & \\
Hindus & 3.41 & .545 & & \\
\hline
\end{tabular}

The result of the ANOVA analysis involving level of education is presented in Table 5 below. It is found that the significant level of the ANOVA test was .001 smaller than standard alpha .005. Thus we can accept that respondents' levels of education are significant on awareness of Shariahbased PRS and researcher concluded that at least two groups of educational level are significantly different. 
Thus, researcher performed the same further analysis using post hoc test of group difference. It is evidenced that the degree and master $(p=.017)$ as well as the degree and PhD $(p=0.005)$ are significantly different. It is concluded that the postgraduate students (Masters and PhD students) are having high level awareness of Shariah-based PRS compared to undergraduate student. Result was supported by Kattak and Rehman (2010). They indicated that academic qualification has a significant influence towards financial awareness.

\begin{tabular}{lcccc} 
Table 5: The difference between level of education and awareness of Shariah-based PRS \\
\multicolumn{1}{c}{ Level of education } & Mean & Std. deviation & F value & Sig. \\
\hline Degree & 3.21 & .638 & & \\
Master & 3.41 & .530 & 7.71 & .001 \\
PhD & 3.67 & .551 & & \\
\hline
\end{tabular}

The aspect of education is further analyses by looking into the background of different programmes under the category of business related studies. The result of the ANOVA analysis for the background of study is presented in the Table 6 below. It was found that the significant level of the ANOVA test is 0.00 smaller than standard alpha .005. Thus the at least two groups of different background of study are significantly different can be accepted.

In identifying the programme with high level of awareness, the researcher performed further analysis using post hoc test of group differences. A close comparison is conducted on background of study according to Islamic business and accounting courses $(p=1.000)$, Islamic business and business management $(\mathrm{p}=0.128)$, also Islamic business, economic finance and banking $(\mathrm{p}=0.816)$. It is evidenced that economic finance and banking students has a high level of awareness towards Shariah-based PRS if compared to other courses. It is supported by Chen and Volpe (1998) as they indicated that students who have study under financial background are more knowledgeable and aware toward financial institutions products.

\begin{tabular}{lcccc}
\hline \multicolumn{5}{c}{ Table 6.The difference between background of study and awareness of Shariah-based PRS } \\
\hline Islamic business & Mean & Std. deviation & F value & Sig. \\
Accounting & 3.38 & .530 & & \\
Business management & 3.39 & .584 & 7.73 & .000 \\
Economic finance and banking & 3.14 & .560 & & \\
\hline
\end{tabular}

\section{Conclusion}

From this study concluded that demographic factors that is gender, age, religion, level of education and background of study has a major influence in influencing students awareness on Shariah -based PRS. Also previous study revealed that those factors tested are significant on awareness of Shariah-based financial products. As from this study male was found out to have high level of awareness on Shariah-based compared to women. It was concluded that all of the demographic variables have significant different with regards to the awareness of Shariah-based PRS. In the aspect of gender, it is found that there is a significant influence between gender and the awareness of Shariah-based PRS. The results indicated that male respondents are more aware of the Shariah-based PRS compared to female. From the perspective of age group, the outcome of this study suggested that there is a significant difference between age group and the awareness of Shariah-based PRS. Based on ANOVA analysis, students in age group 25 years and above has a high level of awareness if compared to others age group. In addition, it was found that there are significant different between the religion of the respondents on the awareness of Shariah-based PRS. On the level of education, postgraduate students show higher level or awareness of Shariahbased PRS as compared to undergraduate students. Surprisingly, those students who are undergoing economic, finance and banking programme has a higher level of awareness of Shariahbased PRS than those in Islamic business.

On overall this study is also provides a room for researches in Shariah-based retirement planning for Muslim society and to share the reward in the hereafter. Besides, this study also contributes to the literature review and validated new instruments in study Shariah-based retirement scheme that is still in infant stage in Malaysia. So those future researchers are able to make a review from this study for their research regarding Shariah-based private retirement scheme either locally or globally. 
In addition this study may help Malaysian government in encouraging Shariah-based PRS to be empowered for the benefits of Malaysian. The government also may play a role in giving a support to the Malaysia Securities industry especially regarding Shariah-based PRS industry.

Since this study is based on the survey approach, it is primarily depending on the willingness of students to answer well the questionnaire. Sometimes respondents do not willing to answer the questionnaires at all. Also limited time measurement for data collection and questionnaire survey are the key limitation for this study.

Last but not least as this study is for the securities industry in Malaysia and the Shariahbased PRS is still in the infant stage, so more research must be done from different angle to look in depth the implication of this scheme and the advantages and disadvantages of it in Malaysia especially among the employers and employees. Also, another study may focus on other population of respondents like employees, employers and also financial providers itself.

\section{Appendix A. Supplementary material}

Supplementary data associated with this article can be found, in the online version, at https://dx.doi.org/10.14254/jems.2017.2-2.9.

\section{Funding}

The authors received no direct funding for this research.

\section{Citation information}

Yahaya, S., Ibrahim, H., Zulkafli, A. H., \& Razimi, M. (2017). Demographics factors and awareness on Shariah-based Private Retirement Scheme among higher learning institution students in Malaysia. Economics, Management and Sustainability, 2(2), 86-94. doi:10.14254/jems.2017.2-2.9.

\section{References}

Amin, H. (2007). Borneo Islamic Automobile Financing: Do Demographics Matter?. Labuan eJournal of Muamalat and Society, 1(1), 68-81.

Chen, H., \& Volpe, R. P. (1998). An analysis of personal financial literacy among college students. Financial Services Review, 7(2), 107-128.

Chen, H., \& Volpe, R. P. (2002). Gender differences in personal financial literacy among college students. Financial Services Review, 11(3), 289-307.

Clark, R. L., d'Ambrosio, M. B., McDermed, A., \& Sawant, K. (2006). Retirement plans and saving decisions: the role of information and education. Journal of Pension Economics and Finance, 5(01), 45-67.

Dale, L. R., \& Bevill, S. (2007). An analysis of the current status of student debt: Implications for helping vulnerable students manage debt. Academy of Educational Leadership Journal, 11(2), 121.

Doraisamy, B., Shanmugam, A., \& Raman, R. (2011). A study on consumers" preferences of Islamic banking products and services in Sungai Petani.Academic Research International, 1(3), 290302.

Dusuki, A. W., \& Abdullah, N. I. (2006). Customers" perceptions of Islamic hire-purchase facility in Malaysia: an empirical analysis. IIUM Journal of Economics and Management, 14(2), 177-204.

Haque, A., Osman, J., \& Ismail, A. Z. (2009). Factor Influences Selection of Islamic Banking: A Study on Malaysian Customer Preferences. American Journal of applied Sciences, 922-928.

Harrison, T., Waite, K., \& White, P. (2006). Analysis by paralysis: the pension purchase decision process. International Journal of Bank Marketing, 24(1), 5-23.

James, J., Hadley Leavell, W., \& Maniam, B. (2002). Financial planning, managers, and college students. Managerial Finance, 28(7), 35-42.

Khan, M. S. N., Hassan, M. K., \& Shahid, A. I. (2008). Banking behavior of Islamic bank customers in Bangladesh. Journal of Islamic Economics, Banking and Finance, 3(2), 159-194.

Khattak, N. A. (2010). Customer satisfaction and awareness of Islamic banking system in Pakistan. African Journal of Business Management, 4(5), 662. 
Loo, M. (2010). Attitudes and perceptions towards Islamic banking among Muslims and nonMuslims in Malaysia: implications for marketing to baby boomers and $\mathrm{x}$ generation. International Journal of Arts and Sciences, 3(13), 453-485.

Tennyson, S., \& Nguyen, C. (2001). State curriculum mandates and student knowledge of personal finance. Journal of Consumer Affairs, 35(2), 241-262.

Yusof, M. Y. R. (1999). Islamic banking: adoption of a service innovation (Doctoral dissertation, Nanyang Technological University, Nanyang Business School).

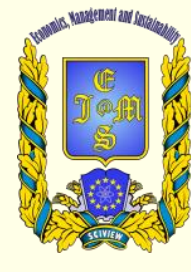

(c) 2016-2017, Economics, Management and Sustainability. All rights reserved.

This open access article is distributed under a Creative Commons Attribution (CC-BY) 4.0 license.

You are free to:

Share - copy and redistribute the material in any medium or format Adapt - remix, transform, and build upon the material for any purpose, even commercially.

The licensor cannot revoke these freedoms as long as you follow the license terms.

Under the following terms:

Attribution - You must give appropriate credit, provide a link to the license, and indicate if changes were made.

You may do so in any reasonable manner, but not in any way that suggests the licensor endorses you or your use.

No additional restrictions

You may not apply legal terms or technological measures that legally restrict others from doing anything the license permits.

Economics, Management and Sustainability (ISSN: 2520-6303) is published by Scientific Publishing House "CSR", Poland, EU and Scientific Publishing House "SciView", Poland

Publishing with JEMS ensures:

- Immediate, universal access to your article on publication

- High visibility and discoverability via the JEMS website

- Rapid publication

- Guaranteed legacy preservation of your article

- Discounts and waivers for authors in developing regions

Submit your manuscript to a JEMS at http://jems.sciview.net or submit.jems@sciview.net 